O. В. Шефер, В. В. Борщ, О. Б. Борщ

Національний університет «Полтавська політехніка імені Юрія Кондратюка», Полтава, Україна

\title{
90 РОКІВ ДІЯЛЬНОСТІ НАЦІОНАЛЬНОГО УНІВЕРСИТЕТУ «ПОЛТАВСЬКА ПОЛІТЕХНІКА ІМЕНІ ЮРІЯ КОНДРАТЮКА»
}

Історія Національного університету «Полтавська політехніка імені Юрія Кондратюка» бере початок з 12 грудня 1818 року, коли за ініціативи генерал-губернатора Полтавської та Чернігівської губерній, героя Вітчизняної війни 1812 р. М.Г. Рєпніна-Волконського та його дружини Варвари Олексіївни - онуки останнього гетьмана Лівобережної України Кирила Розумовського, доньки тогочасного міністра освіти Олексія Розумовського, палкої прихильниці культурно-просвітницьких ідей, в Полтаві було засновано Інститут шляхетних панн що став першим середнім навчальним закладом закритого типу для жінок-дворянок на терені губернських міст російської самодержавної імперії. Найбагатший полтавський поміщик-благодійник С.М. Кочубей (нащадок В.Л. Кочубея) надав частину своєї полтавської садиби, у якій і розмістився цей середній навчальний заклад закритого типу для дівчаток із збіднілих дворянських родин.

Відомо, що М.Г. Рєпнін-Волконський, українець за походженням, зробив суттєвий внесок в розбудову освіти на Полтавщині. Ним, окрім створення інституту шляхетних панн було засновано кадетський корпус у Полтаві. М.Г. Рєпнін-Волконський цікавився історією України, співчуваючи українському автономістському руху, послідовно відстоював інтереси українського населення перед російським урядом. Погляди М.Г. Рєпніна-Волконського призвели до його усунення Миколою I з посади генерал-губернатора та еміграції за кордон.

У період губернаторства М.Г. Рєпніна-Волконського протягом 1828-1832 років за планом архітектурної забудови, виконаними зодчими О.Штаубертом і Л. Шарлеманем, було збудовано приміщення для Полтавського інституту шляхетних панн на частині полтавської садиби найбагатшого полтавського поміщика-благодійника С.М. Кочубея (нащадок В.Л. Кочубея).

Нині це приміщення є центральним корпусом, складовою ансамблю будов Національного університету «Полтавська політехніка імені Юрія Кондратюка» (рис. 1).

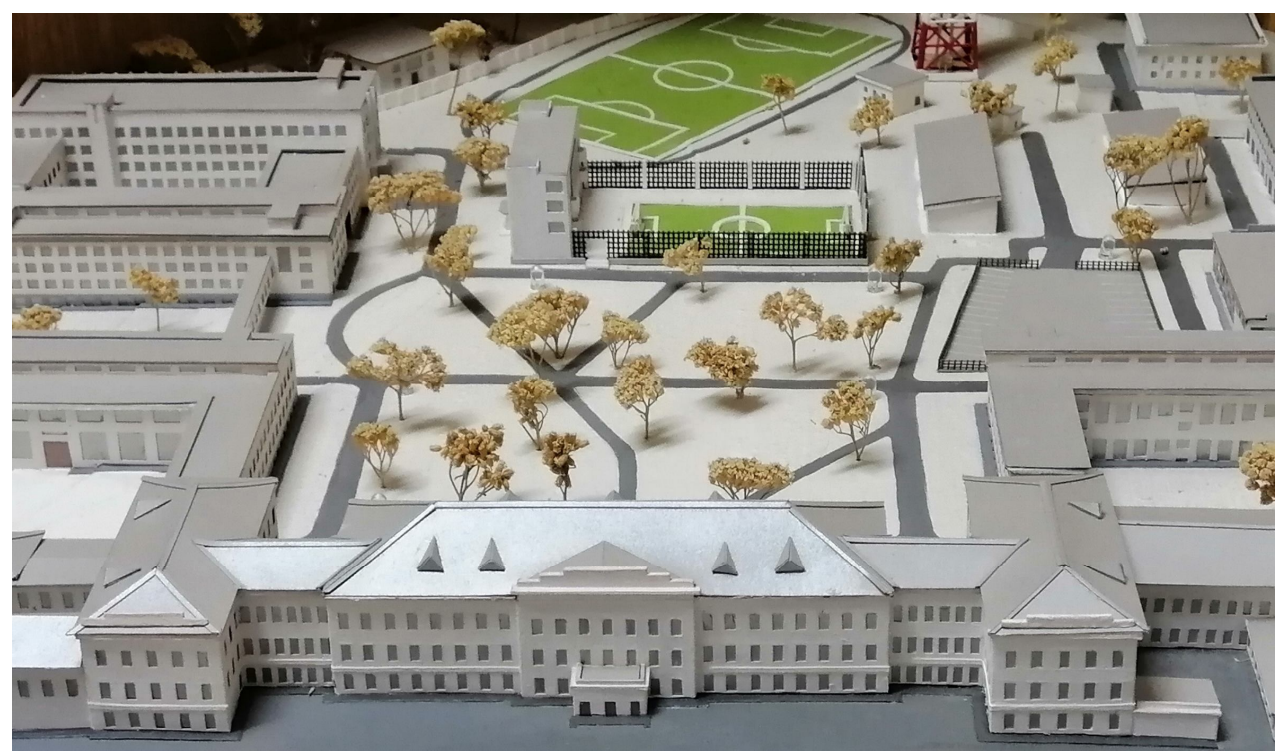

Рис. 1. Сучасний макет будівель і споруд Національного університету «Полтавська політехніка імені Юрія Кондратюка»

За столітній період діяльності в Інституті шляхетних панн у різні роки працювали видатні діячі української, російської і чеської культур. Зокрема, відомий український поет-байкар, професор П. П. Гулак-Артемовський, видатний український і російський поет, драматург В. В. Капніст, відомі піаністи и композитори, збирачі українського фольклору - чехи Алоїз і Венцеслав Єдлічки, 
художники Іван Зайцев, Катерина Рощина, Василь Волков, гравер Сплітстессер, зачинатель українського романтизму Левко Боровиковський та інші.

Інститут шляхетних панн закінчили відомі особистості, серед них: Варвара Рєпніна (донька В.О. та М.Г. Рєпніних, «добрий ангел» Т. Шевченка, який присвятив їй поему «Тризна»); представниці полтавської гілки нащадків О.С. Пушкіна та М.В. Гоголя: Софія, Наталія, Марія, Тетяна, Анна та Олена Бикови; художниця Юлія Волкова; доньки П. П. Гулака-Артемовського; відома українська письменниця-демократка Любов Яновська (у дівоцтві Любов Щербачова), творчість і громадську діяльність якої високо поціновували І.Я. Франко та М.М. Коцюбинський.

Зі стін інституту вийшли всесвітньо відома співачка, актриса, Олександра Сантагано (у дівоцтві баронеса фон Мезенкампф), скульпторка Єлизавета Трипільська, художниця Глафріра Псьол та поетеса Олександра Псьол, Олександра Шейдеман - майбутня дружина Панаса Мирного.

У різні роки інститут шляхетних панн відвідували І. П. Котляревський, Т. Г. Шевченко, М. В. Гоголь, В. А. Жуковський, декабристи Сергій та Матвій Муравйови-Апостоли, що без сумніву суттєво вплинуло на загальну атмоссреру та зміст навчально-виховного процесу в інституті.

У січні 1918 року через складну військово-політичну ситуацію в Україні Інститут шляхетних панн було евакуйовано до Владикавказу.

У період з 1918 по 1930 роки в будові центрального корпусу колишнього Інституту шляхетних панн працювали різноманітні установи землевпорядний технікум, дитячий притулок, школа садівництва благодійна організація «Ліга порятунку дітей», яку очолював письменник В.Г. Короленко, та інші заклади й організації.
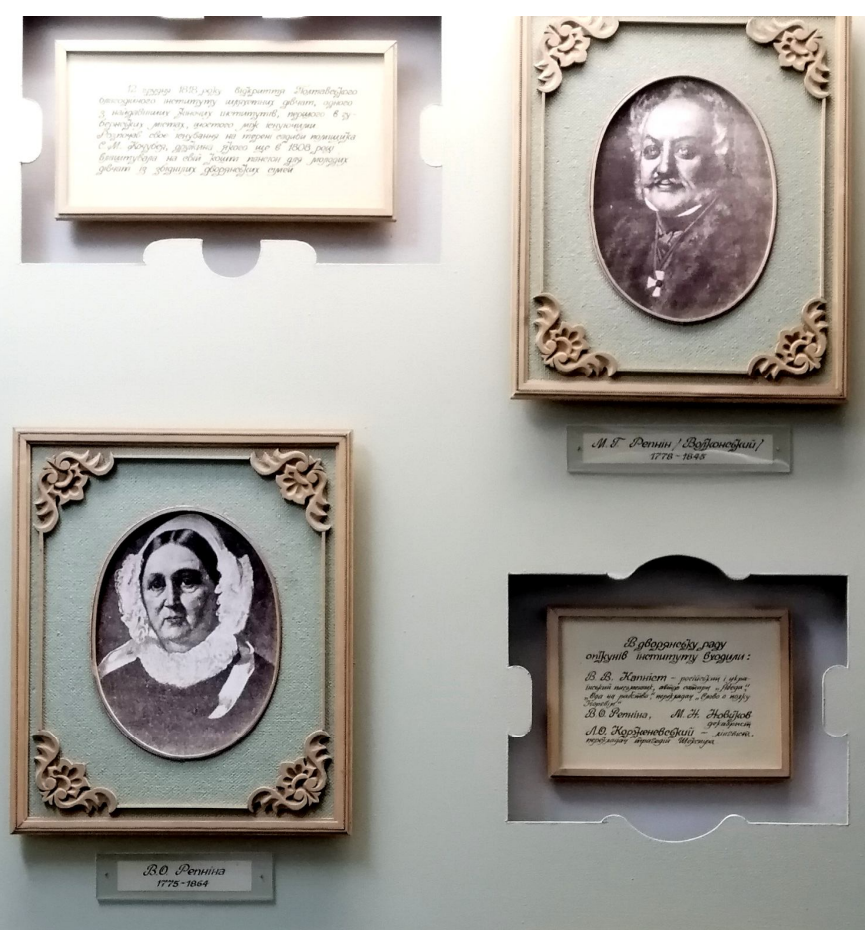

\section{У 30 -ті роки минулого сторіччя в}

Радянському Союзі виникла гостра потреба в інженерно-будівельних кадрах для сільського господарства та промисловості. Залучення іноземних спеціалістів не задовольняло потреб молодої країни, що швидко розвивалася. Відповідно до постанови уряду СРСР від 23 липня 1930 р. за № 237 про утворення нових вищих навчальних закладів, наркомат земельних справ українського уряду видав 19 серпня 1930 року наказ про утворення Полтавського інституту сільськогосподарського будівництва. За рішенням Полтавської міської ради для інституту було виділено приміщення колишнього Інституту шляхетних панн. Так був створений Всесоюзний центр підготовки інженерів сільськогосподарського будівництва в м. Полтава.

На п'яти кафедрах єдиного на той час будівельного фракультету новоствореного вищого навчального закладу працювало 33 викладачі та навчалися 282 студенти. Приєднання у 1933-1934 роках фракультету сільськогосподарського будівництва Саратовського інституту сільського будівництва разом із 200 студентами до Полтавського інституту сільськогосподарського будівництва суттєво розширило його освітні можливості. 
Уже в 1940 році в інституті навчалося понад 500 студентів. За десять довоєнних років колектив інституту підготував понад 800 дипломованих спеціалістів - інженерів-будівельників для села.

На початку Великої вітчизняної війни(Другої світової війни) інститут було евакуйовано до міста Уральськ.

За період 1941-1945 pp. в Полтавському інституті сільськогосподарського будівництва підготовлено понад 2000 інженерів-будівельників. 267 студентів, викладачів та співробітників інституту воювали на фронтах Великої вітчизняної війни. Викладач інституту - доцент Д.М. Батищев особисто встановив прапор перемоги на початку травня 1945 року на одній 3 адміністративних будов у центрі Берліна.

Подвиги загиблих студентів, викладачів та співробітників інституту на фрронтах Великої вітчизняної війни(Другої світової війни) увіковіченні пам'ятником, встановленим на території Національного університету «Полтавська політехніка імені Юрія Кондратюка».

Після звільнення Полтави від німецько-фрашистських загарбників колектив інституту 19 жовтня 1943 року розпочав відбудову навчальних корпусів. Повне відновлення будівлі завершилося у 1955 році.

У 1961 році за наказом Міністерства вищої і середньої спеціальної освіти України № 12 від 9.01.1961 р. інститут перейменовано в Полтавський інженерно-будівельний інститут.

Упродовж 1954-1971 років відбувалось розширення будівельних профілів, за якими здійснювалась підготовка спеціалістів.

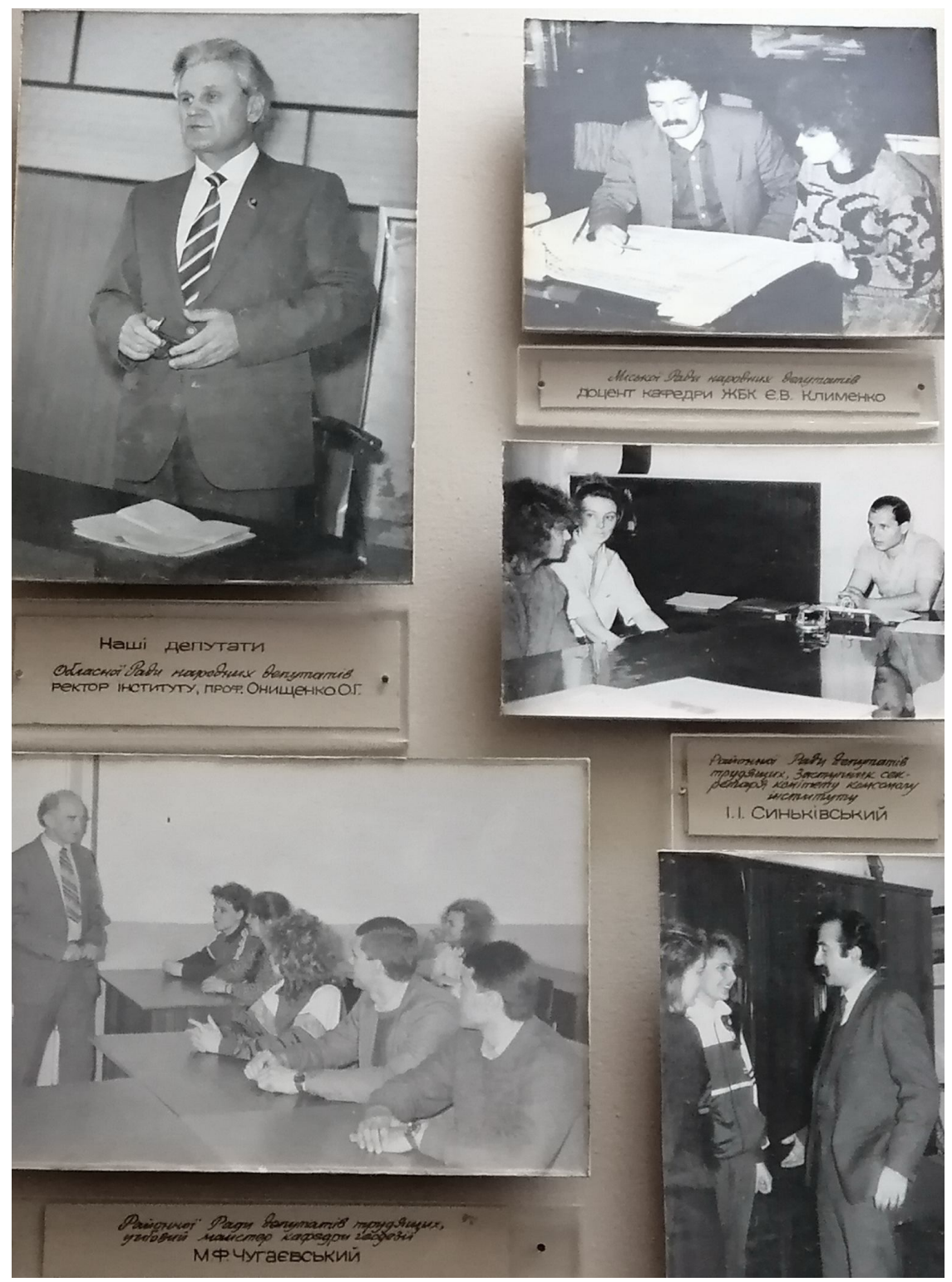

Рис. 3. Становлення фрлагмана вищої освіти Полтавщини 
Становлення та розвиток університету в різні періоди визначався його очільниками. Це: Д.І. Ілляшенко (1930 - 1934 рр.), Т.Т. Манько (1934 - 1937 рр.), Л. М. Даманський (1938 - 1953 рр.), І.С. Доценко (1953 - 1982 рр.), О.Г. Онищенко (1982- 2003 рр.) 32003 року університет очолює доктор економічних наук, професор, Заслужений працівник освіти України, лауреат Державної премії України в галузі науки і техніки Володимир Олександрович Онищенко.

31992 року колектив навчального закладу реформується із монопрофрільного будівельного інституту до багатопрофільного закладу вищої освіти.

Завдяки кропіткій роботі професорсько-викладацького колективу навчального закладу над підготовкою навчальних робочих програм та планів, навчально-лабораторної і матеріальнотехнічної бази, науково-методичної літератури створено передумови успішної акредитації університету за IV, найвищим, міжнародним рівнем та перейменування його згідно з рішенням Кабінету Міністрів України від 29 серпня 1994 року на Полтавський технічний університет.

21 червня 1997 року з нагоди відзначення передовою громадськістю світу, України 100-річного ювілею від дня народження видатного теоретика космонавтики Юрія Кондратюка, рішенням уряду Полтавському технічному університету присвоєно його ім'я.

За рішенням Президента України 27 березня 2002 Університет отримав статус «Національний» і дістав назву «Полтавський національний технічний університет імені Юрія Кондратюка».

Увіковічення пам'яті видатного полтавця, вченого-винахідника, інженера, одного 3 піонерів ракетної техніки та теорії космічних польотів Юрія Кондратюка в ПолтНТУ відбулось 30 травня 2017 року з нагоди 120-ої річниці від Дня його народження відкриттям пам'ятника. Відомо, що завдяки розрахункам Юрія Кондратюка американські космонавти вперше побували на Місяці.

Сьогодні Національний університет «Полтавська політехніка імені Юрія Кондратюка» став потужним міжнародним авторитетним науковим й інноваційним центром - лідером на ринку освітніх послуг, у якому фрнкціонує 8 структурних підрозділів, навчається більше 5000 студентів, серед них близько 400 - іноземних громадян, діють 92 освітні програми, успішно впроваджуються сучасні тренди та підходи до викладання.

Колектив університету налічує близько 10 тисяч осіб, освітній процес забезпечують 350 докторів наук і професорів, кандидатів наук і доцентів.

Протягом багатьох років в університеті сформувалися та працюють 10 загальновизнаних потужних наукових шкіл, які очолюють учені, відомі в Україні, та за її межами. Звання лауреатів Державних премій України в галузі науки і техніки отримали 10 співробітників, звання лауреатів премій Президента України для молодих учених - 19, а звання почесних професорів університету 33, серед яких 7 іноземних громадян.

Високий науково-методичний потенціал дозволяє університету, що є членом Великої хартії університетів, активно інтегруватися до світового освітнього простору та розширювати географрію міжнародних партнерів, яких нині налічується близько ста.

2 серпня 2019 року наказом №1054 Міністерства освіти і науки України Полтавський національний технічний університет імені Юрія Кондратюка отримав новий виток у розвитку та нову назву - Національний університет «Полтавська політехніка імені Юрія Кондратюка».

Органічне поєднання класичних освітніх традицій, узагальнення багаторічних набутків із надсучасними новітніми технологіями та генерацією нових креативних ідей дозволило динамічно трансформувати потужний заклад вищої освіти технічного спрямування в багатопрофільний європейський університет класичного типу, що дозволяє студентам опановувати не тільки технічні спеціальності, але й вивчати мистецтво, фрілологію, право, фрінанси та економіку, займатися спортом, гармонійно інтелектуально та духовно розвиватися. За бажанням студент може навчатись на кількох спеціальностях одночасно.

Створена в університеті надсучасна матеріально-технічна база упродовж декількох останніх років суттєво оновилась, завдяки залученню інвестицій від провідних міжнародних компаній.

Молодь має унікальні можливості займатися 3D-моделюванням, робототехнікою, проводити наукові дослідження, випробування, займатися спортом в найсучасніших лабораторіях і майданчиках, працювати у навчальних філіях установ-партнерів університету, створювати власні стартапи і навіть успішно започаткувати власний бізнес. Разом із Інноваційним холдингом Sikorsky Challenge у 2018 році відкрито єдину на Полтавщині стартап-школу.

Зміст освітніх програм постійно адаптується для формування професійних компетенцій у майбутніх фахівців для роботи із сучасними технологіями. 

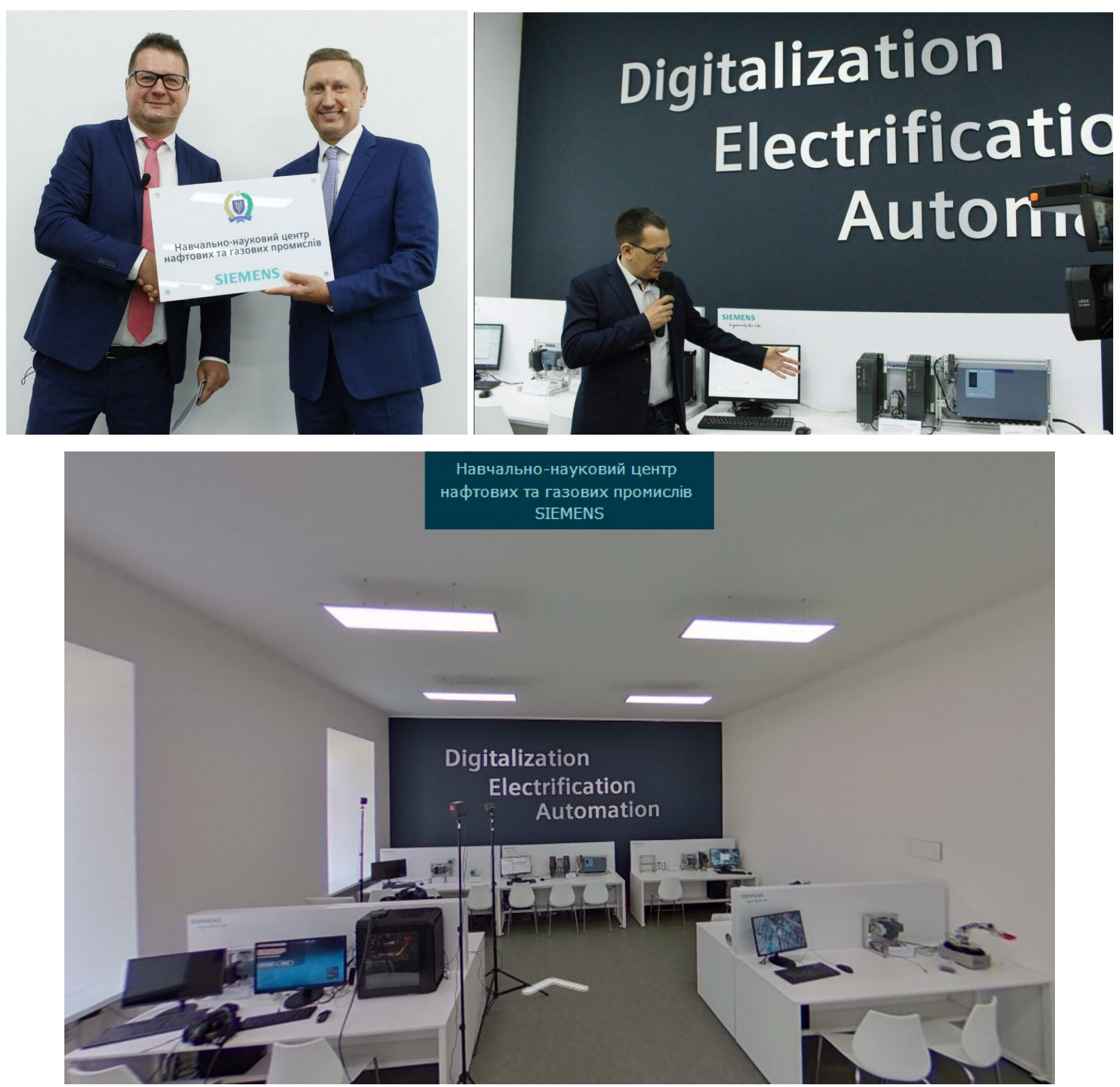

Рис. 4. Найбільша європейська технологічна компанія Siemens відкрила в Національному університеті «Полтавська політехніка імені Юрія Кондратюка» перший в Україні сучасний навчально-науковий центр нафртових і газових промислів

Велику увагу керівництво університету приділяє соціально корисним проєктам та громадській діяльності. Національний університет «Полтавська політехніка імені Юрія Кондратюка» став осередком популяризації наукової роботи серед молоді та діяльності Полтавського територіального відділення Малої академії наук України, відіграв важливу роль у включенні Національного центру «Малої академії наук України» під егіду ЮНЕСКО. Університет $\epsilon$ майданчиком для розвитку учнівського та студентського спорту всеукраїнського рівня, популяризації здорового способу життя.

\section{СПИСОК ЛІТЕРАТУРИ}

1. Полтавський національний технічний університет імені Юрія Кондратюка: історія і сучасність / Полтава. нац. техн. ун-т ім. Ю. Кондратюка ; [заг. ред. В. О. Онищенко ; відп. ред.: Н. К. Кочерга, В. В. Сажко]. - Полтава : Наш друк, 2010. -299 с.

2. Шандра В. С. Рєпнін Микола Григорович // Енциклопедія історії України : у 10 т. / редкол.: В. А. Смолій (голова) та ін. ; Інститут історії України НАН України. - К. : Наук. думка, 2012. - Т. 9 : Прил. С. С. 190. 944 с. - ISBN 978-966-00-1290-5. - URL : https://nupp.edu.ua/page/istoriya.html 